\title{
Over-expression of 14-3-3 $\sigma$ in budding colorectal cancer cells modulates cell migration in the presence of tenascin- $C$
}

\author{
MUNENORI IDE $^{1,2}$, KANA SAITO $^{1,2}$, SOICHI TSUTSUMI $^{1}$, KAORI TSUBOI $^{1}$, SATORU YAMAGUCHI $^{1}$, \\ TAKAYUKI ASAO $^{1}$, HIROYUKI KUWANO ${ }^{1}$ and TAKASHI NAKAJIMA ${ }^{2}$ \\ Departments of ${ }^{1}$ General Surgical Science (Surgery I), and ${ }^{2}$ Tumor Pathology (Pathology II), Gunma University \\ Graduate School of Medicine, 3-39-22 Showa-machi, Maebashi, Gunma 371-8511, Japan
}

Received July 10, 2007; Accepted September 3, 2007

\begin{abstract}
Epigenetic silencing of the 14-3-3б gene by $\mathrm{CpG}$ hypermethylation has been reported in many kinds of cancers, but has been considered inapplicable in the colorectal variety. The expression of 14-3-3 $\sigma$ in colorectal cancer is located primarily in the invasive area. The interaction between tumor cells and the extracellular matrix (ECM) is involved in tumor invasion. In the current study, we investigated the correlation between 14-3-3 $\sigma$ expression and the ECM, focusing especially on the presence of tenascin-C (TNC) at the invasive area of colorectal cancers. Correlations between the immunohistochemical expression of 14-3-3 $\sigma$ and TNC, as well as other clinicopathological factors, were evaluated in 123 colorectal carcinoma tissues. 14-3-3o expression was frequently observed in budding tumor cells in the invasive area and expression was significantly correlated with budding formation $(\mathrm{p}=0.001)$, pTNM classification $(\mathrm{p}=0.001)$ and stromal TNC expression $(p=0.004)$. Using colorectal cancer cell lines and ECMs, the up-regulation of 14-3-3 $\sigma$ mRNA levels was investigated by semi-quantitative RT-PCR. TNC surrounding the tumor cells increased 14-3-3 $\sigma$ mRNA expression 1.8- to 2.2-fold

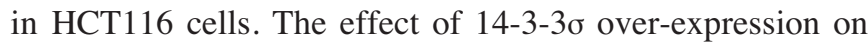
tumor cell migration was investigated using an agarose-cell droplet migration assay. Over-expression of 14-3-3o upregulated HCT116 cell migration on TNC $(\mathrm{p}<0.001)$. We concluded that the expression of 14-3-3 $\sigma$ in the invasive area modulates tumor cell migration in certain types of colorectal cancer and thus facilitates tumor progression.
\end{abstract}

Correspondence to: Dr Munenori Ide, Department of General Surgical Science (Surgery I), Gunma University Graduate School of Medicine, 3-39-22 Showa-machi, Maebashi, Gunma 371-8511, Japan

E-mail: muide@showa.gunma-u.ac.jp

Abbreviations: ECM, extracellular matrix; FN, fibronectin; TNC, tenascin-C

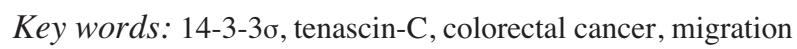

\section{Introduction}

14-3-3 proteins are involved in the modulation of diverse signal transduction pathways (1). They can form homodimers or heterodimers, may act as adapter proteins, and can alter the subcellular localization of various cellular proteins. Previous studies have shown that 14-3-3 proteins play a role in cell cycle regulation (2), apoptosis (3), cell adhesion (4) and cell skeleton dynamics (5).

The family of 14-3-3 proteins is highly conserved in mammalian species and may be divided into seven isotypes

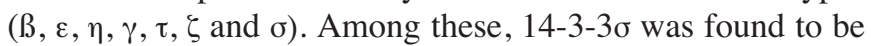
directly related to human cancers and was originally identified as a p53-inducible gene that responded to DNA damage (6). By sequestering $\mathrm{CDC} 2$-cyclin $\mathrm{B} 1$ complexes as they are transported from the nucleus to the cytoplasm, 14-3-3o prevents the cell from entering mitosis (7). It can bind cdk2 or cdk 4 complexes to block transitions in the eukaryotic cell cycle and is regarded as a negative regulator of cell cycle progression (8). In many kinds of carcinoma, e.g. breast (9), stomach (10), liver (11), prostate (12) and lung small cell

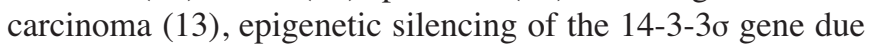
to $\mathrm{CpG}$-hypermethylation in the promoter region has been detected at a very high frequency. Loss of 14-3-3 $\sigma$ protein expression may contribute to malignant transformation by impairing the G2 cell cycle checkpoint function. However, in a previous study we demonstrated that hypermethylation of

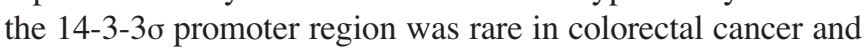

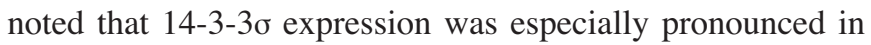
the invasive area (14).

There has yet to be a report on the effect of 14-3-3o expression on cell migration. Martin reported that 14-3-3 $\tau$ had a positive effect on tumor cell adhesion and growth on tenascin-C (TNC) (15). TNC modulates the adhesion of cells to fibronectin $(\mathrm{FN})$ and can be classified as an anti-adhesive or adhesion-modulating extracellular matrix (ECM) protein (16). The expression of TNC is transiently observed in organogenesis, but is absent or very limited in fully developed organs. However, it reappears in inflammation, infection and tumorigenesis.

In this study, we report that 14-3-3 $\sigma$ expression modulates tumor cell migration in colorectal cancer and interacts with $\mathrm{TNC}$ in the invasive area. 


\section{Materials and methods}

Tissue samples. Human colorectal cancer tissue samples were obtained from 123 patients who underwent colorectal resection at Surgery I, Gunma University Hospital. None of the patients had received chemotherapy or radiotherapy prior to surgery. Freshly removed samples were immediately fixed with $10 \%$ buffered formalin for $48 \mathrm{~h}$ and then paraffin-embedded for immunohistochemical analysis. Histological diagnosis and staging were established following TNM classification. The study was approved by the local Committee of Medical Ethics, and all patients gave their written consent.

Immunohistochemical analysis. Immunohistochemical analysis was performed using a streptavidin-horseradish peroxidase (HRP) biotin-staining method. Briefly, after being deparaffinized and rehydrated, $3 \mu \mathrm{m}$-thick serial paraffin sections were incubated with rabbit polyclonal anti-14-3-3o antibody (IBL, Fujuoka, Japan) at a 1:200 dilution or with mouse monoclonal anti-TNC antibody (IBL) at a 1:200 dilution overnight at $4^{\circ} \mathrm{C}$. A secondary biotinylated antibody was then added followed by incubation with a streptavidinHRP conjugate, and the color reaction was developed with diaminobenzidine. Counter-staining was performed using Mayer's hematoxylin. Each sample was classified according to clinicopathological factors, tumor differentiation, depth of tumor invasion, vessel invasion, nodal status and pTNM stage. We focused particularly on tumor budding, defined as small clusters of undifferentiated tumor cells that appeared ahead of the lesion's invasive front. Tumor budding cells were divided into two groups according to degree, defined as the number of 'budding' foci in the hematoxylin-eosin stained tissue sample observed within a microscopic field of x200. The negative group contained $<5$ foci and the positive $\geq 5$ foci.

Cell lines and extracellular matrices. Human colon cancerderived HCT116 cells and SW480 cells were cultured in RPMI-1640 medium (Sigma-Aldrich Japan K.K., Tokyo, Japan) containing $10 \%$ fetal calf serum at $37^{\circ} \mathrm{C}$ and $5 \% \mathrm{CO}_{2}$. The substrates TNC and FN were prepared by coating wells with these proteins at 25 or $50 \mu \mathrm{g} / \mathrm{ml}$ in PBS including $0.01 \%$ Tween for $30 \mathrm{~min}$ to $2 \mathrm{~h}$ at $37^{\circ} \mathrm{C}$. Human TNC and FN were purchased from Chemicon (Temecula, CA).

Semi-quantitative RT-PCR. One million wild-type HCT116 or SW480 cells were cultured in $10 \mathrm{~cm}$ dishes coated with TNC or FN. After $48 \mathrm{~h}$ the cells were harvested and total-RNA was extracted with an RNeasy kit (Qiagen K.K., Tokyo, Japan) according to the manufacturer's instructions. Using $5 \mu \mathrm{g}$ totalRNA from each sample, reverse transcription was performed with a SuperScript II kit (Invitrogen K.K., Tokyo, Japan).

PCR was performed using the following specific primer pair: 14-3-3 $\sigma, 5$ '-AGCAGAAAAGCAACGAGGAG-3' and 5'-GGGCAACACTCAGCTCT-3'; products, 560 bp. As an internal control, GAPDH was used: 5'-GAAGGTGAAGGTC GGAGTC-3' and 5'-GAAGATGGTGATGGGATTTC -3'; products, $212 \mathrm{bp}$. PCR conditions were as follows: 1 cycle at $95^{\circ} \mathrm{C}$ for $10 \mathrm{~min}, 10-28$ cycles at $95^{\circ} \mathrm{C}$ for $45 \mathrm{sec}, 56^{\circ} \mathrm{C}$ for $30 \mathrm{sec}, 72^{\circ} \mathrm{C}$ for $45 \mathrm{sec}$ and $1 \mathrm{cycle}$ at $72^{\circ} \mathrm{C}$ for $10 \mathrm{~min}$. PCR products $(5 \mu 1)$ were run on $8 \%$ polyacrylamide gel and

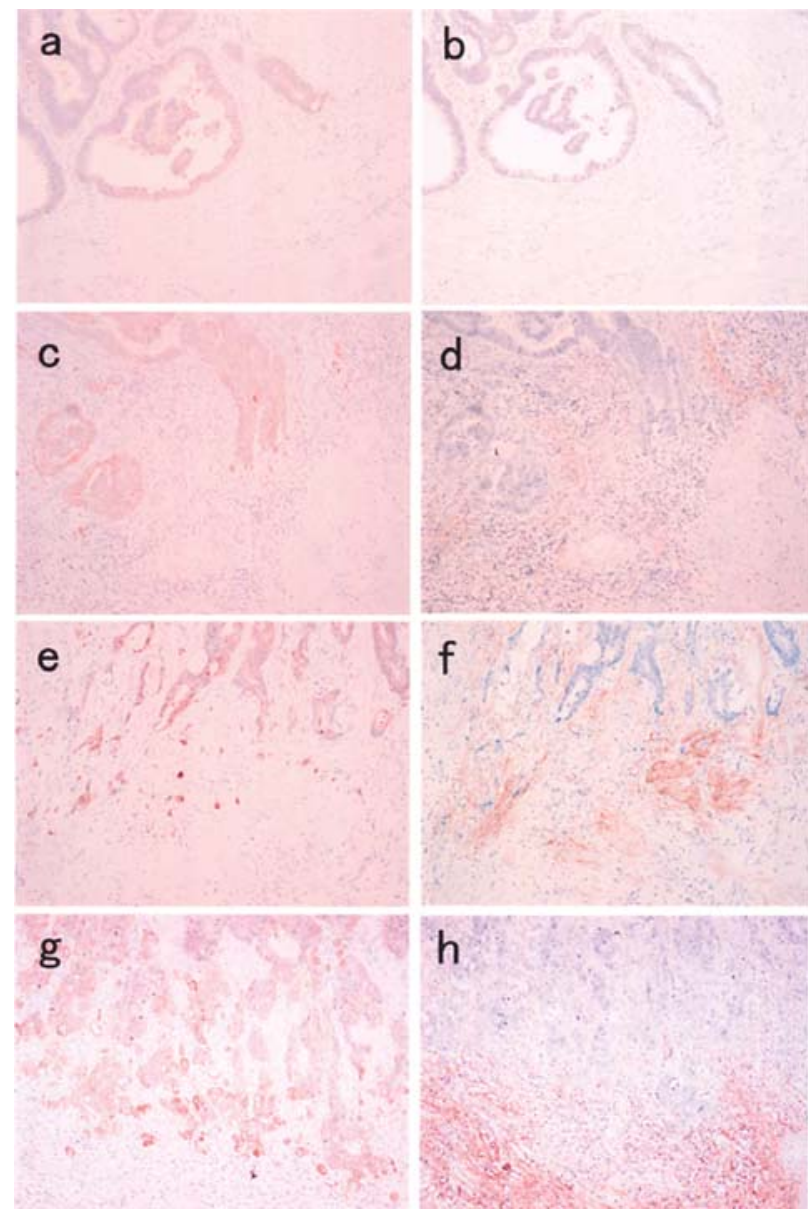

Figure 1. Immunohiostochemical analysis of 14-3-3 $\sigma$ and TNC expression in

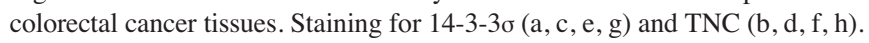
Weak staining of $14-3-3 \sigma$ was observed in $<5 \%$ of tumor cells at the invasive area (a). Trace staining for TNC was observed (b). This case was regarded

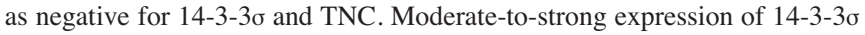
was observed in $>5 \%$ of large clusters of tumor cells at the invasive area and relatively strong 14-3-3 $\sigma$ expression was observed in budding cells (c, e, g). Focally weak-to-moderate expression of TNC was observed. This case was regarded as negative for TNC (d). Diffuse moderate and focally strong (f) and diffuse strong expression (h) of TNC. These cases were regarded as positive for TNC. Original magnification, $\mathrm{x} 100$.

observed by ethidium bromide staining under ultraviolet light. Photographic images of the gels were stored on a computer. Scion Image software was used for densitometric analysis. The experiment was repeated three times.

Plasmids and transfections. pCDNA4-14-3-3o, an expression vector for 14-3-30, was a generous gift from Dr T. Kino (National Institute of Health, Bethesda, MD) (17). As a negative control, pCDNA4 His/Max empty vector (Invitrogen) was used. Both were transfected with Lipofectamin 2000 (Invitrogen) at $1 \mu \mathrm{g} /$ well of the plasmids. Colonies were selected after growth on 50-100 $\mu \mathrm{g} / \mathrm{ml}$ Zeocin (Invitrogen).

Agarose-cell droplet migration assay. To investigate morphological changes and the ability of the tumor cells to migrate from a large cluster to the surrounding ECMs, we used an agarose-cell droplet migration assay. Briefly, solidified cell suspensions in agarose gel were set on a chamber slide then coated with ECM substrate and cultured. 
Table I. Expression of 14-3-3 $\sigma$ and tenascin-C correlated with clinicopathological factors.

\begin{tabular}{|c|c|c|c|c|c|c|c|}
\hline \multirow[b]{2}{*}{ Parameter } & \multirow[b]{2}{*}{$\begin{array}{c}\text { All cases } \\
n=123\end{array}$} & \multicolumn{3}{|c|}{ 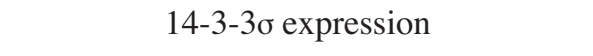 } & \multicolumn{3}{|c|}{ Tenascin-C expression } \\
\hline & & $\begin{array}{c}\text { Negative } \\
\mathrm{n}=52\end{array}$ & $\begin{array}{c}\text { Positive } \\
\mathrm{n}=71\end{array}$ & P-value & $\begin{array}{c}\text { Negative } \\
n=46\end{array}$ & $\begin{array}{c}\text { Positive } \\
\mathrm{n}=77\end{array}$ & P-value \\
\hline \multicolumn{8}{|c|}{ Tumor differentiation } \\
\hline G1 & 60 & 31 & 29 & 0.12 & 25 & 35 & 0.30 \\
\hline G2 & 60 & 20 & 40 & & 19 & 41 & \\
\hline G3 & 3 & 1 & 2 & & 2 & 1 & \\
\hline \multicolumn{8}{|c|}{ Depth of invasion } \\
\hline pT1 & 72 & 40 & 32 & $<0.001$ & 30 & 42 & 0.07 \\
\hline pT2-3 & 51 & 12 & 39 & & 16 & 25 & \\
\hline \multicolumn{8}{|l|}{ Budding } \\
\hline Negative & 69 & 38 & 31 & 0.001 & 30 & 39 & 0.11 \\
\hline Positive & 54 & 14 & 40 & & 16 & 38 & \\
\hline \multicolumn{8}{|c|}{ Lymphatic invasion } \\
\hline Negative & 54 & 31 & 23 & 0.002 & 28 & 26 & 0.003 \\
\hline Positive & 69 & 21 & 48 & & 18 & 51 & \\
\hline \multicolumn{8}{|c|}{ Venous invasion } \\
\hline Negative & 82 & 45 & 37 & $<0.001$ & 31 & 51 & 0.999 \\
\hline Positive & 41 & 7 & 34 & & 15 & 26 & \\
\hline \multicolumn{8}{|c|}{ Nodal status } \\
\hline pN0 & 89 & 47 & 42 & $<0.001$ & 40 & 49 & 0.005 \\
\hline $\mathrm{pN} 1-3$ & 34 & 5 & 29 & & 6 & 28 & \\
\hline \multicolumn{8}{|c|}{ pTNM classification } \\
\hline Stage I & 63 & 37 & 26 & $<0.001$ & 27 & 36 & 0.024 \\
\hline Stage II & 24 & 10 & 14 & & 12 & 12 & \\
\hline Stage III & 36 & 5 & 31 & & 7 & 29 & \\
\hline \multicolumn{8}{|l|}{ Tenascin-C } \\
\hline Negative & 46 & 27 & 19 & 0.004 & & & \\
\hline Positive & 77 & 25 & 52 & & & & \\
\hline
\end{tabular}

The $2 \%$ low-melting point agarose (Wako, Osaka, Japan) in PBS was re-melted and diluted to $0.2 \%$ in $37^{\circ} \mathrm{C}$ preheated serum-free RPMI-1640 medium. HCT116 cells $\left(1 \times 10^{6}\right)$ or SW480 cells transfected with plasmids were re-suspended in this medium to a final cell concentration of $1 \times 10^{4}$ cells $/ \mu 1$.

Droplets $(1 \mu \mathrm{l})$ were placed in the center of a well on a 16-well Lab-Tech chamber slide (Nalge Nunc International, Cambridge, MA) and refrigerated at $4^{\circ} \mathrm{C}$ for $10 \mathrm{~min}$ to allow the aragose droplets to set. Then, $50 \mu 1$ coating solution $(25 \mu \mathrm{g} /$ $\mathrm{ml}$ TNC or $50 \mu \mathrm{g} / \mathrm{ml} \mathrm{FN}$ ) was dropped onto the agarose gel droplet. After $30 \mathrm{~min}$ incubation at $37^{\circ} \mathrm{C}, 150 \mu \mathrm{l}$ of RPMI-1640 containing $10 \%$ FCS was added. After $48 \mathrm{~h}$ incubation, the medium was removed and cells were fixed with $10 \%$-buffered formalin then dried. Giemsa staining was performed. The experiment was conducted on three sets of cells and ECMs.

To evaluate cell migration ability and migratory cell density in the invasive area, we measured the migratory distance traveled in four directions starting from the edge of the droplet and counted the number of cells within the $200 \mu \mathrm{m}^{2}$ visualized in the invasive area.

Statistical analysis. Fisher's exact test was used for the statistical analysis of tumor 14-3-3o and stromal TNC expression. The t-test was used to analyze the association between two categorical variables in the agarose-cell droplet migration assay. A P-value of $<0.05$ was considered to be statistically significant.

\section{Results}

Immunohistochemical analyses. The assessment of 14-3-3o or TNC expression was focused on the tumor invasive area. 14-3-3 $\sigma$ or TNC expression in the tumor surface or center was excluded from the assessment. 14-3-3o expression was 


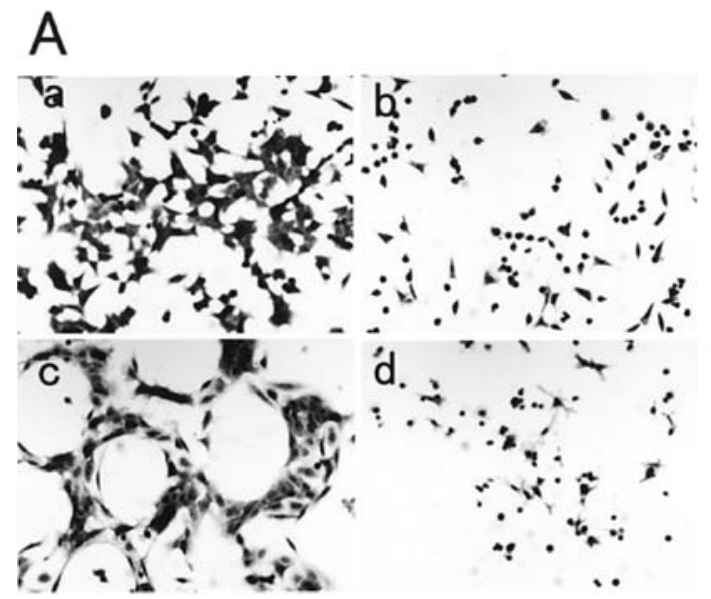

$\mathrm{B}$

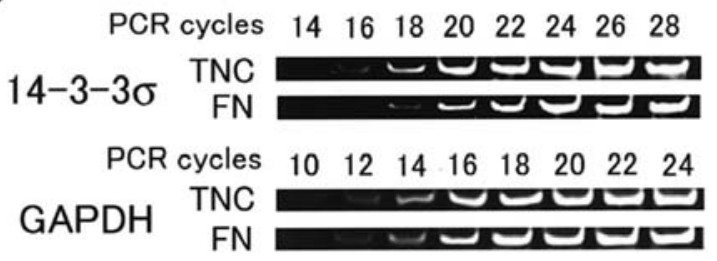

Figure 2. (A) Giemsa staining for tumor cells cultured on TNC or FN for $24 \mathrm{~h}$. HCT116 (a) and SW480 (c) cells cultured on FN showed well-stretched epithelial cell-like morphology with cell-to-cell contact. HCT116 (b) and SW480 (d) cells cultured on TNC showed less attached round shapes and lost cell-to-cell contact. Original magnification, x200. (B) Semi-quantitative RT-PCR for comparison of 14-3-3o induction in HCT116 cells cultured on TNC or FN for $24 \mathrm{~h}$. GAPDH was used as an internal control. Densitometric analysis indicated that the expression level of GAPDH on both ECMs was equal. At PCR cycles 18 and 20, the expression level of 14-3-3o mRNA in HCT116 cells on TNC revealed ratios of 1.8-2.2 relative to FN-cultured cells.

observed primarily in tumor cell cytoplasm. No specific staining was observed in the stromal cells (Fig. 1a). More than $10 \%$ of tumor cells in the invasive area showed moderate-tostrong immunoreactivity, which we regarded as 14-3-3o positive (Fig. 1g). We observed several cases with strong 14-3-3 $\sigma$ expression localized in more than five budding foci (Fig. 1c and e). These cases were also regarded as positive. In all, 71 cases $(57.7 \%)$ were regarded as $14-3-3 \sigma$ positive. In 37 $(30 \%)$ of these, $14-3-3 \sigma$ expression was localized primarily in the budding cells. TNC expression was observed primarily in the ECM component of the tumor-surrounding stroma. Diffuse ( $>50 \%$ of stroma) moderate-to-strong expression (Fig. 1h) or focally (25-50\% of stroma) strong expression of TNC in the invasive area (Fig. 1f) was regarded as positive. There were 77 cases $(62.6 \%)$ positive for TNC. Diffuse moderate-to-strong expression of TNC was observed in 38 cases (30.8\%) and focally strong expression in 39 cases $(31.7 \%)$.

Clinicopathological parameters and expression of 14-3-3 $\sigma$ and TNC are illustrated in Table I. Significant correlations were found between 14-3-3 $\sigma$ expression and deeper invasion $(\mathrm{p}<0.001)$, tumor budding $(\mathrm{p}=0.001)$, lymphatic invasion $(\mathrm{p}=0.002)$, venous invasion $(\mathrm{p}<0.001)$, lymph node metastasis $(\mathrm{p}<0.001)$ and advanced pTNM stage $(\mathrm{p}<0.001) .14-3-3 \sigma$ expression in the invasive area of colorectal cancer was correlated with tumor progression. TNC expression was also significantly correlated with tumor progression, lymphatic invasion $(\mathrm{p}=0.033)$, lymph node metastasis $(\mathrm{p}=0.005)$ and
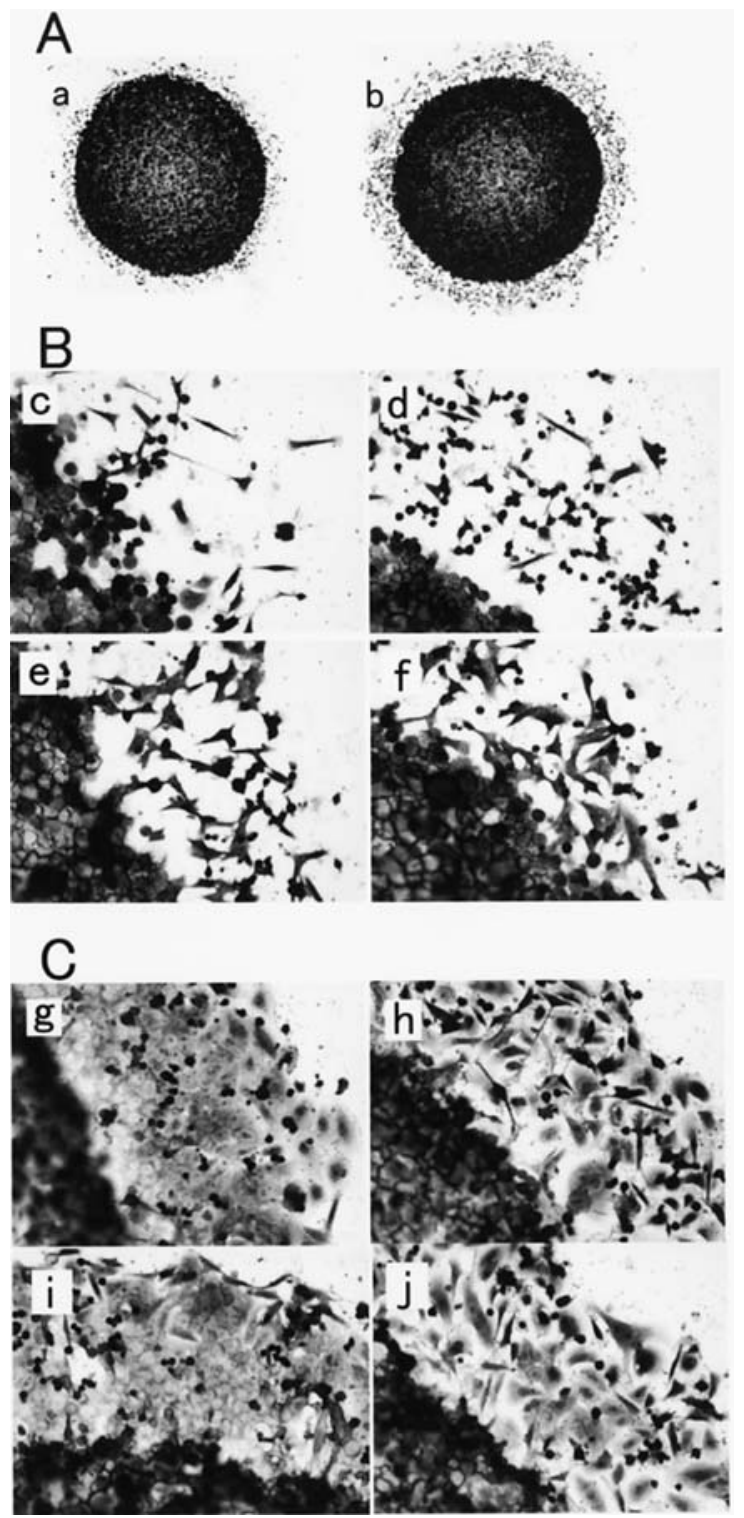

Figure 3. Giemsa staining of agarose-cell droplet and migratory cells. (A) Migratory cells radiated out from the droplet. MOCK HCT116 (a) and 1433OE HCT116 (b) cells on TNC. Original magnifications x20. (B) HCT116 cells on TNC showed a rounded and less attached form. 1433OE HCT116 cells (d) were well-spreading compared to MOCK HCT116 cells (c). On FN, there was no significant difference between MOCK HCT116 and $1433 \mathrm{OE}$ HCT116 (e, f). Original magnifications x200. (C) MOCK SW480 cells showed dense expansive growth on TNC (g) and FN (i). 1433OE SW480 cells were relatively well-stretched and had loose cell-to-cell contact on two different ECMs (h, j). Original magnification, x200.

advanced pTNM stage $(\mathrm{p}=0.024)$. There was a tendency towards a correlation between tumor budding and stromal TNC expression $(\mathrm{p}=0.11)$. Survival analysis according to Kaplan-Meier analysis revealed no significant correlation between the expression of 14-3-3 $\sigma$ or TNC and survival (data not shown). There was a positive correlation between tumor cell $14-3-3 \sigma$ and stromal TNC expression $(\mathrm{p}=0.004)$.

Morphological change and induction of 14-3-3 $\sigma$ in cancer cell lines cultured on TNC and FN. As shown by immunohisto-

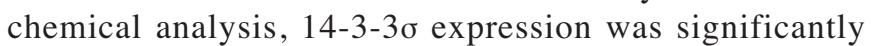
correlated with TNC expression. We therefore investigated whether TNC modulated 14-3-3o expression in tumor cells. 
Table II. Forced 14-3-3 $\sigma$ expression and tumor cell migration.

\begin{tabular}{|c|c|c|c|}
\hline Extracellular matrix & Fibronectin & Tenascin-C & P-value \\
\hline \multicolumn{4}{|c|}{ Migration distance $(\mu \mathrm{m})$} \\
\hline MOCK HCT116 & $414.5 \pm 15.3^{\mathrm{a}}$ & $262.7 \pm 13.9^{\mathrm{a}, \mathrm{b}}$ & $<0.001^{\mathrm{a}}$ \\
\hline 1433OE HCT116 & $403.1 \pm 22$ & $459.7 \pm 32.7^{b}$ & $<0.001^{\mathrm{b}}$ \\
\hline \multicolumn{4}{|c|}{ Cell density (cells/200 $\mu \mathrm{m}^{2}$ ) } \\
\hline MOCK HCT116 & $22.7 \pm 2.1^{\mathrm{c}}$ & $10.3 \pm 1.1^{\mathrm{c}, \mathrm{d}}$ & $<0.001^{\mathrm{c}}$ \\
\hline 1433OE НCT116 & $23.7 \pm 1.6$ & $31.0 \pm 1.4^{\mathrm{d}}$ & $<0.001^{\mathrm{d}}$ \\
\hline \multicolumn{4}{|c|}{ Migration distance $(\mu \mathrm{m})$} \\
\hline MOCK SW480 & $183.6 \pm 20.1^{\mathrm{e}}$ & $235 \pm 13.7^{\mathrm{e}}$ & $0.046^{\mathrm{e}}$ \\
\hline 1433OE SW480 & $204.5 \pm 11.2^{\mathrm{f}}$ & $208.9 \pm 11.8^{\mathrm{f}}$ & $\mathrm{NS}^{\mathrm{f}}$ \\
\hline \multicolumn{4}{|c|}{ Cell density (cells $/ 200 \mu \mathrm{m}^{2}$ ) } \\
\hline MOCK SW480 & $221.7 \pm 4.6^{\mathrm{g}}$ & $224.6 \pm 4.0^{\mathrm{h}}$ & $<0.001^{\mathrm{g}}$ \\
\hline 1433OE SW480 & $104.4 \pm 2.8^{g}$ & $103.2 \pm 2.4^{\mathrm{h}}$ & $<0.001^{\mathrm{h}}$ \\
\hline
\end{tabular}

NS, not significant.

First, HCT116 or SW480 cells were grown in medium containing $10 \%$ FCS for $24 \mathrm{~h}$ on plates coated with FN or TNC. When grown on these substrates, the cells showed a completely different morphology. On FN, two cell lines had well-stretched epithelial cell-like morphology (Fig. 2A, a and c) whereas, on TNC, they completely lost cell-to-cell contact and formed round or irregular shapes with a long pseudopodium (Fig. 2A, b and d).

Second, we isolated mRNA from HCT116 and SW480 cells grown on FN or TNC. As shown in Fig. 2B, for HCT116 cells the transcript levels of GAPDH were equal, while 14-3-3o levels were 1.8- to 2.2-fold increased when cultured on TNC compared to FN. However, SW480 cells showed no significant difference in 14-3-3 $\sigma$ levels between cells cultured on FN vs. TNC (data not shown).

Agarose-cell droplet migration assay. The budding cells in the invasive area of colorectal cancer showed strong expression

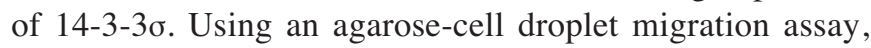

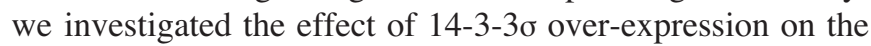
migration of cells from a large cell cluster to the ECM. Migratory cells radiating out from the droplet were observed. HCT116 cells had different responses when grown on different ECMs. On TNC, migratory cells from the HCT116 agarosecell droplet showed a round less attached morphology (Fig. 3B, $\mathrm{c}$ and d). The migration of empty plasmid transfected (MOCK) HCT116 cells was suppressed on TNC in comparison with those grown on FN (Table II, $\mathrm{p}<0.001^{\mathrm{a}, \mathrm{b}}$ ). However, migratory HCT116 cells that over-expressed 14-3-3o (1433OE) showed a significantly longer migration distance $\left(\mathrm{p}<0.001^{\mathrm{c}}\right)$ and higher cell density $\left(\mathrm{p}<0.001^{\mathrm{d}}\right)$ in the migratory area compared to MOCK HCT116 cells (Fig. 3A, a and b; Fig. 3B, c and d; Table II). On FN, there was no significant difference in migratory distance or cell density between 1433 OE HCT 116 cells and MOCK HCT116 cells (Fig. 3B, e and f).
For SW480 cells, TNC accelerated the migration of MOCK SW480 cells compared to those grown on FN ( $\left.\mathrm{p}=0.046^{\mathrm{e}}\right)$. However, 1433OE SW480 cells showed no significant difference in migration distance (NS $)$. 14-3-3o overexpression also modulated migratory cell morphology and density. MOCK SW480 cells showed very high-density expansive growth on both TNC and FN (Fig. 3C, g and i) $\left(\mathrm{p}<0.001^{\mathrm{g}}, \mathrm{p}<0.001^{\mathrm{h}}\right) .1433 \mathrm{OE}$ SW480 cells showed relatively well-stretched and loose cell-to-cell contact on two different ECMs (Fig. 3C, h and j).

\section{Discussion}

Previous trends in research involving 14-3-3 $\sigma$ in oncology have indicated an epigenetic negative regulation of its gene. Recently, the observed decrease in 14-3-3o expression in tumors was found to be a sporadic event, even in breast cancer (18). Moreover, the expression of 14-3-3o was increased in pancreatic cancer (19). A recent study of colorectal cancer

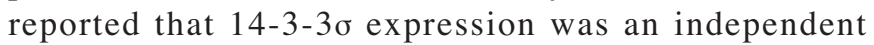
prognostic factor for poor survival (20). In the present study, we demonstrated that 14-3-3 $\sigma$ expression in the invasive area was significantly correlated with the tumor progression of colorectal cancer.

It has been previously reported that the down-regulation of 14-3-3o was observed in invasive transitional cell carcinoma and corresponded to lesions undergoing epithelial mesenchymal transition (EMT), a phenomena in which cells dissociate from the epithelia and migrate freely, contributing to the invasive and metastatic processe (21). Invasion by colorectal carcinoma is characterized by an EMT-like dedifferentiation of tumor cells (22). EMT is characterized by the expression of FN and vimentin in conjunction with an absence of E-cadherin. Therefore, EMT and tumor cell budding might not be exactly the same event. However, these phenomena involve a morphological transformation of migratory tumor cells in response to the micro-environment of the invasive area. When grown on TNC, tumor cells show a rounded less attached form. We found that TNC can upregulate 14-3-3 $\sigma$ expression in HCT116 cells. Over-expression of 14-3-3 $\sigma$ accelerates the migration of HCT116 cells on TNC and induces loose cell-to-cell contact in migrated SW480 cells regardless of the ECM type. Recently, Beiter reported that $ß$-catenin induced TNC in colorectal cancer cells (23). In this report, it presented that TNC is inducible in SW480 but not in HCT116 cells. The different response of colorectal cancer cell lines HCT116 and SW480 to TNC, which we observed in the experiment in which we induced 14-3-3 $\sigma$ and carried out a migration assay, might be derived from this character.

Immunohistochemically, budding colorectal cancer tissue cells show strong staining for 14-3-3 $\sigma$ and their expression was significantly correlated with TNC expression in the invasive area. Based on our observations and experiments, the existence of TNC and the over-expression of 14-3-3 $\sigma$ may be closely linked to the formation of budding cells. The critical

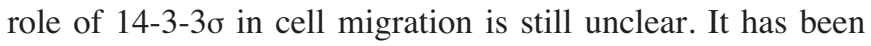
reported that 14-3-3 $\sigma$ has a function in preventing apoptosis by sequestering BAX (24). The adhesiveness of some types of colorectal cancer cells may be altered by TNC and 14-3-3o 
over-expressed budding cells in the invasive area may gain an anti-apoptotic function for cell survival.

Understanding the interaction between tumor cells and stromal ECMs will contribute to the treatment of cancers. However, it is controversial whether 14-3-3 $\sigma$ is an opponent or an ally in the development of new cancer therapies $(25,26)$. The induction of 14-3-3o expression may become a key point of control in new methods of chemo-radiation therapy for cancer.

\section{Acknowledgements}

The authors are grateful to Masako Saito, Futoshi Hara and Toshiaki Hikino for technical advice, and to Hideko Emura for secretarial assistance.

\section{References}

1. Mhawech P: 14-3-3 proteins - an update. Cell Res 15: 228-236, 2005.

2. Lopez-Girona A, Furnari B, Mondesert O and Russell P: Nuclear localization of $\mathrm{Cdc} 25$ is regulated by DNA damage and a 14-3-3 protein. Nature 397: 172-175, 1999

3. Xing $\mathrm{H}$, Zhang S, Weinheimer C, Kovacs A and Muslin AJ: 14-3-3 proteins block apoptosis and differentially regulate MAPK cascades. EMBO J 19: 349-358, 2000.

4. Han DC, Rodriguez LG and Guan JL: Identification of a novel interaction between integrin beta1 and 14-3-3beta. Oncogene 20: 346-357, 2001.

5. Gohla A and Bokoch GM: 14-3-3 regulates actin dynamics by stabilizing phosphorylated cofilin. Curr Biol 12: 1704-1710, 2002.

6. Hermeking H, Lengauer C, Polyak K, He TC, Zhang L, Thiagalingam S, Kinzler KW and Vogelstein B: 14-3-3 sigma is a p53-regulated inhibitor of G2/M progression. Mol Cell 1: 3-11, 1997.

7. Chan TA, Hermeking H, Lengauer C, Kinzler KW and Vogelstein B: 14-3-3Sigma is required to prevent mitotic catastrophe after DNA damage. Nature 401: 616-620, 1999.

8. Laronga C, Yang HY, Neal C and Lee MH: Association of the cyclin-dependent kinases and 14-3-3 sigma negatively regulates cell cycle progression. J Biol Chem 275: 23106-23112, 2000.

9. Ferguson AT, Evron E, Umbricht CB, Pandita TK, Chan TA, Hermeking H, Marks JR, Lambers AR, Futreal PA, Stampfer MR and Sukumar S: High frequency of hypermethylation at the 14-3-3 sigma locus leads to gene silencing in breast cancer. Proc Natl Acad Sci USA 97: 6049-6054, 2000.

10. Suzuki H, Itoh F, Toyota M, Kikuchi T, Kakiuchi H and Imai K: Inactivation of the 14-3-3 sigma gene is associated with 5' CpG island hypermethylation in human cancers. Cancer Res 60: 4353-4357, 2000

11. Iwata N, Yamamoto H, Sasaki S, Itoh F, Suzuki H, Kikuchi T, Kaneto H, Iku S, Ozeki I, Karino Y, Satoh T, Toyota J, Satoh M, Endo $\mathrm{T}$ and Imai K: Frequent hypermethylation of $\mathrm{CpG}$ islands and loss of expression of the 14-3-3 sigma gene in human hepatocellular carcinoma. Oncogene 19: 5298-5302, 2000.
12. Henrique R, Jeronimo C, Hoque MO, Carvalho AL, Oliveira J, Teixeira MR, Lopes C and Sidransky D: Frequent 14-3-3 sigma promoter methylation in benign and malignant prostate lesions. DNA Cell Biol 24: 264-269, 2005

13. Osada H, Tatematsu Y, Yatabe Y, Nakagawa T, Konishi H, Harano T, Tezel E, Takada $\mathrm{M}$ and Takahashi T: Frequent and histological type-specific inactivation of 14-3-3sigma in human lung cancers. Oncogene 21: 2418-2424, 2002.

14. Ide M, Nakajima T, Asao $\mathrm{T}$ and Kuwano $\mathrm{H}$ : Inactivation of 14-3-3sigma by hypermethylation is a rare event in colorectal cancers and its expression may correlate with cell cycle maintenance at the invasion front. Cancer Lett 207: 241-9, 2004.

15. Martin D, Brown-Luedi M and Chiquet-Ehrismann R: Tenascin-C signaling through induction of 14-3-3 tau. J Cell Biol 160: $171-175,2003$.

16. Chiquet-Ehrismann R, Chiquet M: Tenascins: regulation and putative functions during pathological stress. J Pathol 200: 488-499, 2003.

17. Kino T, Souvatzoglou E, De Martino MU, Tsopanomihalu M, Wan Y and Chrousos GP: Protein 14-3-3sigma interacts with and favors cytoplasmic subcellular localization of the glucocorticoid receptor, acting as a negative regulator of the glucocorticoid signaling pathway. J Biol Chem 278: 25651-25656, 2003.

18. Moreira JM, Ohlsson G, Rank FE and Celis JE: Down-regulation of the tumor suppressor protein 14-3-3sigma is a sporadic event in cancer of the breast. Mol Cell Proteomics 4: 555-569, 2005.

19. Guweidhi A, Kleeff J, Giese N, Fitori JE, Ketterer K, Giese T, Buchler MW, Korc M and Friess H: Enhanced expression of 14-3-3sigma in pancreatic cancer and its role in cell cycle regulation and apoptosis. Carcinogenesis 25: 1575-1585, 2004.

20. Perathoner A, Pirkebner D, Brandacher G, Spizzo G, Stadlmann S, Obrist P, Margreiter R and Amberger A: 14-3-3sigma expression is an independent prognostic parameter for poor survival in colorectal carcinoma patients. Clin Cancer Res 11: 3274-3279, 2005 .

21. Moreira JM, Gromov $\mathrm{P}$ and Celis JE: Expression of the tumor suppressor protein 14-3-3 sigma is down-regulated in invasive transitional cell carcinomas of the urinary bladder undergoing epithelial-to-mesenchymal transition. Mol Cell Proteomics 3: 410-419, 2004.

22. Brabletz T, Jung A, Reu S, Porzner M, Hlubek F, KunzSchughart LA, Knuechel R and Kirchner T: Variable beta-catenin expression in colorectal cancers indicates tumor progression driven by the tumor environment. Proc Natl Acad Sci USA 98: 10356-10361, 2001 .

23. Beiter K, Hiendlmeyer E, Brabletz T, Hlubek F, Haynl A, Knoll C, Kirchner T and Jung A: beta-Catenin regulates the expression of tenascin-C in human colorectal tumors. Oncogene 24: 8200-8204, 2005.

24. Samuel T, Weber HO, Rauch P, Verdoodt B, Eppel JT, McShea A, Hermeking $\mathrm{H}$ and Funk JO: The G2/M regulator 14-3-3sigma prevents apoptosis through sequestration of Bax. J Biol Chem 276: 45201-45206, 2001.

25. Liu Y, Liu H, Han B, Zhang JT: Identification of 14-3-3sigma as a contributor to drug resistance in human breast cancer cells using functional proteomic analysis. Cancer Res 66: 3248-3255, 2006.

26. Yang H, Wen YY, Zhao R, Lin YL, Fournier K, Yang HY, Qiu Y, Diaz J, Laronga C and Lee MH: DNA Damage-Induced Protein 14-3-3 sigma inhibits protein kinase B/Akt Activation and suppresses Akt-activated cancer. Cancer Res 66: 3096-3105, 2006. 